\title{
A unique case of delayed diagnosis of early onset acquired angioedema
}

\author{
Neil G Parikh ${ }^{1 *}$, Joseph Yusin ${ }^{2}$ and William Klaustermeyer ${ }^{2}$ \\ *Correspondence: Nparikh2009@gmail.com \\ ${ }^{1}$ Clinical Immunology and Allergy Fellow at UCLA-VA Greater Los Angeles Health System, Los Angeles, California, USA. \\ ${ }^{2}$ UCLA-VA Greater Los Angeles Health System, Los Angeles, California, USA.
}

\begin{abstract}
Acquired angioedema (AAE) is a very rare condition caused by an acquired deficiency in $\mathrm{C} 1$ esterase inhibitor (C1 INH). Pathogenesis of AAE can entail abnormal B cell lymphoproliferation ranging from benign monoclonal gammopathy of undetermined significance (MGUS) to malignant forms of lymphoma. Symptoms related to MGUS or malignancy are often salient and age is often used as a diagnostic tool in considering in making this diagnosis. These bradykinin-mediated angioedema episodes commonly involve face, gastrointestinal system, and pharynx with associated potential for fatality and lack associated urticaria. Hence early diagnosis is vital. This case is unique, in that it describes a very early age of presentation of AAE related to MGUS. Given young age and lack of symptoms associated with MGUS, diagnosis was delayed and significant patient morbidity and healthcare expenses occurred which could have been avoided. A 41 year-old male presented to the allergy/immunology clinic with facial, lip, and tongue swelling following tooth extraction. His history began 5 years prior, after suffering complications from a motor vehicle accident including anterograde amnesia, multiple broken ribs, and a splenic hemorrhage requiring splenectomy. Six months after the accident he developed acute onset bilateral facial swelling, lip swelling, and difficulty breathing. He had no family history of angioedema, was not taking any medications, and his serum tryptase level checked during the episode was normal. He was diagnosed with presumed food-induced allergic angioedema. The patient suffered four additional episodes of varying degree over the next five years and developed clinical depression. Immunological evaluation showed low C1-INH, low C1-INH functional percentage, C4, C2, and C1q, consistent with AAE. Further workup to determine the etiology of AAE included serum protein electrophoresis demonstrating an M-spike in the gamma region with immunofixation showing a monoclonal protein band and a serum IgM level of $1.3 \mathrm{~g} / \mathrm{dl}$. The patient was diagnosed with AAE related to MGUS.
\end{abstract}

Keywords: Acquired angioedema, monoclonal gammopathy of undetermined significance, $\mathrm{C} 1$ esterase inhibitor

\section{Background}

Acquired angioedema (AAE) is a very rare condition associated with episodic mucosal swelling commonly involving the face, gastrointestinal system, and pharynx caused by an acquired deficiency in $\mathrm{C} 1$ esterase inhibitor ( $\mathrm{C} 1 \mathrm{INH})$. Pathogenesis of AAE can involve abnormal $B$ cell lymphoproliferation ranging from benign monoclonal gammopathy of undetermined significance (MGUS) to malignant forms of lymphoma. This case describes a very early age of presentation of AAE related to MGUS.

\section{Case presentation}

We present the case of a 41 year-old male who presented to the allergy/immunology clinic after having an episode of facial, lip, and tongue swelling following tooth extraction. His history began five years prior, when he presented to an emergency room after being in a near-fatal motorcycle accident. He had suffered extensive injuries including brain contusions resulting in the development of anterograde amnesia and multiple fractured ribs, as well as splenic hemorrhage requiring splenectomy. Six months later, the patient had an episode of bilateral facial swelling, lip swelling, and difficulty breathing.
He was evaluated in the local emergency room, and was given epinephrine, diphenhydramine, and methylprednisolone. Because of the patient's anterograde amnesia and inability to recall specific food consumed, evaluating physicians assumed he was having a food-related allergic reaction. Tryptase level was checked during the attack and it was found to be $2.8 \mu \mathrm{g} / \mathrm{L}$ (reference range 2.1-13.1). The patient did not have a history of allergies or family history of angioedema. The patient was not taking any medications at that time. The patient was observed in the hospital observation unit for 48 hours and discharged with an epinephrine pen. He subsequently had approximately 4-5 similar episodes of varying degree per year over the next 5 years. He required intubation on one occasion for airway protection. He developed significant depression and required placement in a nursing home.

Given the clinical presentation of recurrent isolated angioedema without urticaria, bradykinin-mediated angioedema was high on the differential. Patient had low C1-INH $12 \mathrm{mg} / \mathrm{dL}$ (21-39), C1-INH functional percentage $1 \%$ ( $<47 \%$ abnormal), C4 $1.67 \mathrm{mg} / \mathrm{dL}$ (16-38), C2 .2 mg/dL (1-4), and C1q <2 mg/dL (7-48). Low levels of C1-INH, C1-INH functional percentage,

() 2013 Parikh et al; licensee Herbert Publications Ltd. This is an Open Access article distributed under the terms of Creative Commons Attribution License (http://creativecommons.org/licenses/by/3.0). This permits unrestricted use, distribution, and reproduction in any medium, provided the original work is properly cited. 
Parikh et al. Hypersensitivity 2013,

and $\mathrm{C} 4$ can also be seen in patients with type 1 HAE (often also with family history of angioedema), however the low C1q level indicated the diagnosis of AAE (reduced in $70 \%$ of patients with AAE) [2]. Workup for AAE included evaluation for both lymphoproliferative and autoimmune disease. Diagnostic testing included complete blood cell count with differential, serum protein electrophoresis, antinuclear antibodies, chest radiograph, and abdominal ultrasound to assess lymphoid tissue. Testing was unrevealing except for serum protein electrophoresis which demonstrated an M-spike in the gamma region, with immunofixation demonstrating a IgM-monoclonal protein band with serum IgM level of $1.3 \mathrm{~g} /$ $\mathrm{dL}$. Subsequent bone marrow biopsy and FISH did not show any clonal abnormalities or evidence of malignancy. Hence, etiology of AAE was determined to be lgM-monoclonal gammopathy of undetermined significance (MGUS). Patient was subsequently started on long term AAE prophylaxis with $600 \mathrm{mg}$ danazol daily, and patient has not had an episode of angioedema in 6 months.

\section{Discussion}

This is a unique case describing early onset AAE related to MGUS with significantly delayed diagnosis. His early age of onset of MGUS as a cause of AAE, physical impairment of amnesia, and misdiagnosis of food allergy were critical in delay of diagnosis. This case highlights the importance of continued understanding and awareness of the different causes of angioedema and early diagnosis.

Acquired angioedema (AAE) is a syndrome characterized by acquired deficiency of $\mathrm{C} 1$ esterase inhibitor (C1-INH), leading to excessive activation of the complement system and subsequent bradykinin-mediated angioedema. As in hereditary angioedema (HAE), which is also bradykinin-mediated, AAE also presents with episodic mucosal swelling involving the oropharynx, larynx, face, genitals, and gastrointestinal tract. Symptoms of face, lip, and tongue swelling as well as life-threatening pharyngeal involvement are typical [1]. AAE diagnosis is often difficult to make because of the lack of family history (present in $\mathrm{HAE}$ ) and trigger that can be obtained via clinical history. Delay in diagnosis leads to an impedance in receiving appropriate treatment. Untreated, recurrent episodes of angioedema lead to significant impairment in quality of life, increased risk of morbidity and death, as well as increased healthcare costs.

$A A E$ is characterized by recurrent angioedema without urticaria, and an acquired deficiency of C1-INH leading to hyperactivation of the complement system. AAE is extremely rare with roughly 100 reported cases in literature [3]. HAE prevalence has been estimated between 1:10,000 and 1:50,000 [4]. AAE is more uncommon with rough estimate prevalence for $A A E$ of $1: 100,000$ and $1: 500,000$. AAE is traditionally related to a $B$ cell disorder ranging from production of anti-C1 INH auto-antibodies to monoclonal gammopathy of undetermined significance and non-Hodgkin lymphoma causing C1
INH consumption. This deficiency of $\mathrm{C} 1 \mathrm{INH}$ leads to activation of the classic complement pathway, and depletion of $\mathrm{C} 1, \mathrm{C2}$, and C4. The contact system is activated, kallikrein is generated that cleaves high molecular weight kinninogen producing bradykinin (primary mediator in AAE) which increases vascular permeability causing mucosal edema [5]. AAE has also rarely been reported in patients with systemic lupus erythematosus (SLE) and other infections. HAE is an autosomal dominant hereditary disease caused by a $\mathrm{C} 1-\mathrm{INH}$ deficiency due to mutations in C1-INH gene (SERPING1 gene) on chromosome 11 [4]. Clinically symptoms are similar to $A A E_{\text {, }}$ but age of onset is earlier. Generally, in HAE initial symptoms manifest in $90 \%$ of the patients during the second decade of life, while in AAE patients are usually over 40 years of age [7]. This case is also unique in that it seems to be one of the youngest patients (36) with AAE that has been reported. Standard treatment for an AAE episode is replacement therapy with plasma-derived C1-INH concentrate ( $\mathrm{pd} \mathrm{C} 1-\mathrm{INH})$, however some patients become progressively less responsive to $\mathrm{pd}$ $\mathrm{C} 1-\mathrm{INH}$ over time. Case studies have shown efficacy in AAE treatment with Icatibant (a selective bradykinin $B_{2}$ receptor antagonist), Ecallantide (a kallikrein inhibitor), and Rituximab (CD20 monoclonal ab) [3-5].

The explanation for delay in diagnosis is multifactorial. The patient being an unreliable historian (anterograde amnesia), lack of knowledge and understanding of AAE in the medical community, and the low prevalence of AAE all contributed to delayed diagnosis. Additionally, a lack of symptoms associated with MGUS, the underlying cause of AAE in this patient, made it more difficult to diagnose. Ability to differentiate other causes of angioedema based on clinical history, triggers, family history, and time of symptom onset can help expedite identification of the etiology. (Table 1) outlines the factors that can be helpful in differential diagnosis. Healthcare costs and psychological studies on the burden of AAE have not been done, but in HAE recurring attacks have been shown to cause significant evidence of depression, decreased work productivity, and overall activity impairment. Additionally, HAE attacks lead to approximately 15,000 to 30,000 emergency department visits each year, with significant associated hospital costs [10]. With new successful advances in HAE (and also AAE since therapy is similar), such psychological impairment and healthcare expenses can be curtailed with early diagnosis.

In summary, we present a unique case of delayed diagnosis of early onset AAE. When evaluating patients with recurrent angioedema without urticaria, clinicians must consider all causes of C1-INH deficiency including AAE. Symptoms related to a cause of AAE like MGUS may be missing but diagnosis should be considered even if of younger age. Delay in diagnosis may lead to unnecessary psychological stress and excessive healthcare expenses.

\section{Competing interests}

The authors declare that they have no competing interests. 
Parikh et al. Hypersensitivity 2013,

http://www.hoajonline.com/journals/pdf/2052-594X-1-2.pdf

doi: $10.7243 / 2052-594 X-1-2$

Table 1. General characteristics of different causes of angioedema.

\begin{tabular}{|c|c|c|c|c|c|c|}
\hline Type of Angioedema & Age of Onset & Location of Edema & $\begin{array}{l}\text { Associated } \\
\text { Urticaria }\end{array}$ & Trigger & Diagnosis & Treatment Principle \\
\hline Histamine-induced & Variable & Variable & YES & $\begin{array}{l}\text { Type } 1 \text { IgE-mediated } \\
\text { hypersensitivity to } \\
\text { food, drugs, or insect } \\
\text { venom }\end{array}$ & $\begin{array}{l}\text { Clinical history, } \\
\text { allergy testing }\end{array}$ & $\begin{array}{l}\text { Identification of } \\
\text { allergy and avoidance, } \\
\text { or desensitization in } \\
\text { certain drugs or venom }\end{array}$ \\
\hline $\begin{array}{l}\text { Angiotensin-converting } \\
\text { enzyme (ACE)-induced }\end{array}$ & $\begin{array}{l}2 / 3 \text { of episodes } \\
\text { occur within first } 3 \\
\text { months of therapy } \\
{[\mathbf{8}]}\end{array}$ & $\begin{array}{l}\text { Lips, tongue, face are } \\
\text { common. Pharyngeal/ } \\
\text { laryngeal reported, GI } \\
\text { tract least likely [8] }\end{array}$ & $\mathrm{NO}$ & $\begin{array}{l}\text { ACE-inhibitor or } \\
\text { aldosterone receptor } \\
\text { blocker (ARB) } \\
\text { medications }\end{array}$ & $\begin{array}{l}\text { Clinical history, use } \\
\text { of ACE-inhibitors }\end{array}$ & $\begin{array}{l}\text { Discontinuation of } \\
\text { medication }\end{array}$ \\
\hline $\mathrm{HAE}$ & $\begin{array}{l}40 \% \text { before age } 5 \text {, } \\
75 \% \text { by age } 15[\mathbf{8}], \\
90 \% \text { within } 2^{\text {nd }} \\
\text { decade [7] }\end{array}$ & $\begin{array}{l}80 \% \text { GI tract } \\
\text { involvement; } \\
\text { laryngeal/pharyngeal, } \\
\text { cutaneous involvement } \\
\text { frequently limbs [7] }\end{array}$ & $\mathrm{NO}$ & $\begin{array}{l}\text { Mild trauma, dental } \\
\text { work, surgery, stress, } \\
\text { cold-exposure, } \\
\text { estrogen-derivatives, } \\
\text { ACE-Inhibitors [4] }\end{array}$ & $\begin{array}{l}\text { Type I: Low C1 INH, } \\
\text { C1 INH function, } \\
\text { C4, normal C1q } \\
\text { Type II: Low C1 } \\
\text { INH function, C4, } \\
\text { normal C1 INH, } \\
\text { C1q } \\
\text { Type III: All normal } \\
\text { complement levels }\end{array}$ & $\begin{array}{l}\text { Airway protection, } \\
\text { C1-INH replacement, } \\
\text { Bradykinin B2 receptor } \\
\text { antagonist (Icatibant), } \\
\text { Kallikrein inhibitor } \\
\text { (Ecallantide) }\end{array}$ \\
\hline AAE & Over $40^{*}$ & $\begin{array}{l}30-50 \% \text { GI tract; } \\
\text { laryngeal/pharyngeal, } \\
\text { cutaneous recurrence } \\
\text { face>limbs [7] }\end{array}$ & No & Similar to HAE & $\begin{array}{l}\text { Low C1 INH, C1 } \\
\text { INH function, C4, } \\
\text { C1q }\end{array}$ & $\begin{array}{l}\text { Treatment of } \\
\text { underlying cause (ie } \\
\text { lymphoma), otherwise } \\
\text { similar to HAE }\end{array}$ \\
\hline
\end{tabular}

*This case describes a patient who presented at age of 36 which is very uncommon.

\section{Authors' contributions}

\begin{tabular}{|l|c|c|c|}
\hline Authors' contributions & NGP & JY & WK \\
\hline Research concept and design & $\checkmark$ & -- & -- \\
\hline Collection and/or assembly of data & $\checkmark$ & -- & -- \\
\hline Data analysis and interpretation & $\checkmark$ & -- & -- \\
\hline Writing the article & $\checkmark$ & -- & -- \\
\hline Critical revision of the article & $\checkmark$ & -- & -- \\
\hline Final approval of article & $\checkmark$ & $\checkmark$ & $\checkmark$ \\
\hline Statistical analysis & -- & -- & -- \\
\hline Other (please specify)... & -- & -- & -- \\
\hline
\end{tabular}

\section{Publication history}

Editors: Guha Krishnaswamy, James H. Quillen V.A. Medical Center, USA.

Celso Pereira, Coimbra University, Portugal.

Received: 29-May-2013 Revised: 16-Jul-2013

Re-revised: 31-Aug-2013 Accepted: 11-Sep-2013

Published: 20-Nov-2013

\section{References}

1. Bork K, Meng G, Staubach P and Hardt J. Hereditary angioedema: new findings concerning symptoms, affected organs, and course. Am J Med. 2006; 119:267-74. I Article | PubMed

2. Wagenaar-Bos IG, Drouet C, Aygoren-Pursun E, Bork K, Bucher C, Bygum A, Farkas H, Fust G, Gregorek H, Hack CE and Hickey A et al. Functional C1-inhibitor diagnostics in hereditary angioedema: assay evaluation and recommendations. J Immunol Methods. 2008; 338:14-20. I Article I PubMed

3. Zingale LC, Castelli R, Zanichelli A and Cicardi M. Acquired deficiency of the inhibitor of the first complement component: presentation, diagnosis, course, and conventional management. Immunol Allergy Clin North Am. 2006; 26:669-90. I Article I PubMed

4. Zuraw BL. Clinical practice. Hereditary angioedema. N Engl J Med. 2008; 359:1027-36. | Article | PubMed
5. Castelli R, Zanichelli A, Cicardi M and Cugno M. Acquired C1-inhibitor deficiency and lymphoproliferative disorders: A tight relationship. Crit Rev Oncol Hematol. 2013; 87:323-32. | Article | PubMed

6. Cicardi M and Zanichelli A. Acquired angioedema. Allergy Asthma Clin Immunol. 2010; 6:14. | Article | PubMed Abstract | PubMed Full Text

7. Bouillet-Claveyrolas L, Ponard D, Drouet $C$ and Massot C. Clinical and biological distinctions between type I and type II acquired angioedema. Am J Med. 2003; 115:420-1. I Article I PubMed

8. Toh S, Reichman ME, Houstoun M, Ross Southworth M, Ding X, Hernandez AF, Levenson M, Li L, McCloskey C, Shoaibi A, Wu E, Zornberg $G$ and Hennessy $S$. Comparative risk for angioedema associated with the use of drugs that target the renin-angiotensin-aldosterone system. Arch Intern Med. 2012; 172:1582-9. | Article I PubMed

9. Bork K, Meng G, Staubach P and Hardt J. Hereditary angioedema: new findings concerning symptoms, affected organs, and course. Am J Med. 2006; 119:267-74. | Article | PubMed

10. Lumry WR, Castaldo AJ, Vernon MK, Blaustein MB, Wilson DA and Horn PT. The humanistic burden of hereditary angioedema: Impact on health-related quality of life, productivity, and depression. Allergy Asthma Proc. 2010; 31:407-14. | Article | PubMed

\section{Citation:}

Parikh NG, Yusin J and Klaustermeyer W. A unique case of delayed diagnosis of early onset acquired angioedema. Hypersensitivity. 2013; 1:2. http://dx.doi.org/10.7243/2052-594X-1-2 